TM-1658

\title{
A Technique for Epoxy Free Winding and Assembly of COS $\theta$ Coils for Accelerator Magnets*
}

\author{
J. A. Carson and R. Bossert \\ Fermi National Accelerator Laboratory \\ P.O. Box 500 \\ Batavia, Illinois 60510
}

September 30, 1986

* Published in the proceedings of the 1986 Applied Superconductivity Conference, , Baltimore, Maryland September 29 - October 3, 1986. 


\author{
S. A. Carson, R. Bossert \\ Ferml Nattonal hecelerator Laboratory \\ P. D. Box 500 \\ Batavia, Illinois 60510
}

\section{Abseract}

iraditional nethods of magnet construction (wet winding) use molded coll subassemblles bonded togetner with epoxy Impregnated (loerglass tape. Thls is a ilghly abor intenstue process involving redundane operations for each of the lour colls. The epoxy (ree wincing technigue (ary winding) aliminates the opoxy curing steps and also allows all four colls to be wound on $a$ common windting mandrel, thereby reducting *lnding stations and handling. The toollng required for dry dinding is a radical departure from existing technology tmposing new mechanleal prodesus. A number of $64 \mathrm{~cm}$ long $5 \mathrm{~cm}$ sperture SSC Design "ge magnets have been produced at fermllao utilizing dry winding technlques. Discussed is the speciallzed tooling creaced to accomplish dry winding as well as new vinding and assembly procedures required. Also discussed are mechanical proolems encountered and their solutions. Baged on experlence galred, dry winding san be a viable lower cost alternaclve to traditional coll taorication technlques.

\section{Introduction}

Dry winding is a term used to describe an epoxy (ree' alternat ve to currently utlllzed (wet vinding) coll winding techniques employing epaxy in the fabrication and zssentily of superconducting accelerator magnets, such as the Tovatron dlpole or the proposed SSC dipole magnet. Dry wholing can offer cose advantages through the reduction of assembly lavor and sapltal quipment for tooling and floor space. A serles of magnets have been produced at Fermilab almed at exploring the reastbility of the ary winding process.

\section{Wet Hinding Versus ory Wlanding}

The wet winding process ut1lizes superconducting cable insulation which has applied to it a "B" stage (thermosetting) epoxy. Th1s can be in the form of epoxy Impregnated Piberglass tape (Tevatron and SSC) or can be epoxy applled directly to the outer surface of the primary insulation (usually polylaide $r ! 1 \mathrm{~m}$ ). The Insulated cable is then wound onto spectal whinding mandrels followed by nolding in preclsion presses under heat and pressure to obtaln the desired coll geowetry. Variations in cable thickness from lot to lot often requires remolding to achlore the desired coll size. The extent of rewolding is ascertalined through measurenent of the molded coll asseably. Thls process is repeated for each of the colls used in the magnet (rour colls for the Tevatron and SSC dealgns). The colls are then assembled onto an assembly mandrel (bean tube for SSC) followed by applleation of appropriate ground plane Insulation and IInally coll clamp collars are applied.

The dry windlng process has no epoxy on the cable insulation. Instead of winding and molding indiridual colls, all the colls are wound onto a special mandrel. Once wound the colls stay on the wandrel whlch is then utllized as an assembly mandrel not to be remored

- Operated by Unlversltles Researen Assoclation, Inc., under contract with the U. S. Department of Energy.

Manuscript recelved Septender 30, 1986. until the clamp collars have been applled. Control of: coll to coll size matening is accoraplished by: selection of caule of uniform size for each of the : colls. This requlres continuous deasurment of the. cable during the Insulation process using a speclallzed measuring cevice ${ }^{2}$. F1g. I lllustraces these differences in the form of a slaplified process. flow enart.

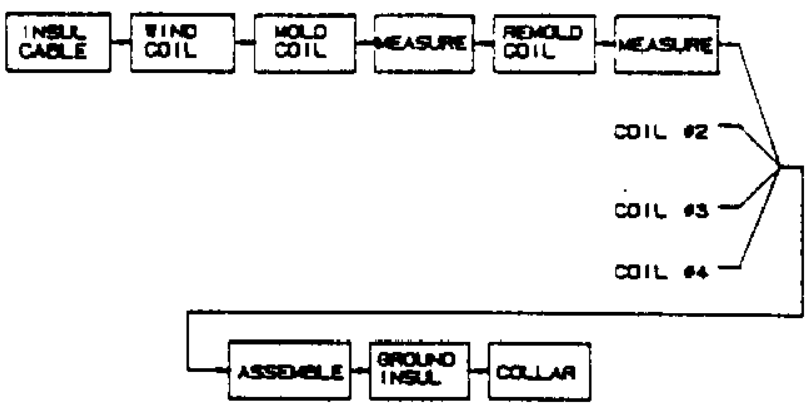

VET UINOING

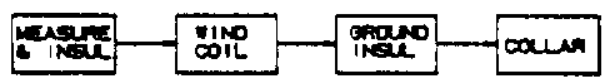

\section{DRY WINDING}

F1g. 1. Process charts showlng the difference in wet and dry winding production process.

\section{Toolln. Uaed In Dry Winding}

to accompltah the task of winding all colls onto a singular aandrel requires that the mandrel expand to accoraodate the uncoupressed coll structure. The expanaion aust be llatted to the vertical plane. An expansion in the norlzontal plane woulo not allow placement of the clamp collars. F18. 2 111ustrates the construction of the expanding wandrels used. Two wandrela were aade, One with 5 co 0.0 . and another 4 o.D. The vertical expansion $1 \mathrm{~s}$ to and $11 \mathrm{man}$ respectlvely.

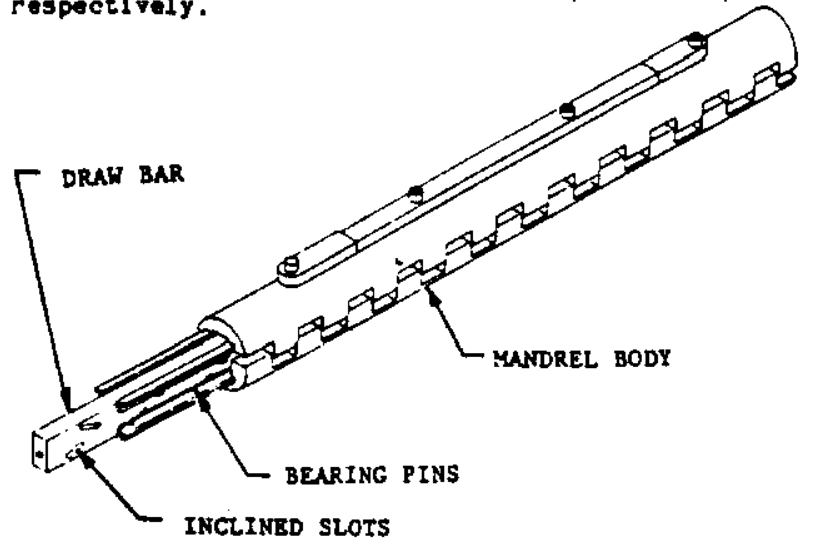

F1g. 2. Illustration or expanded bandrel with end cut away to show mechanlas. 
Two magnet tesigns were (abricated using dry winding: SSC Jesign "g"' (F1g.. 3) j4 am Long and SSC Jeslgn "gn" (Flg. d) 1 meter long. Slxteen Design "g" 3nd two Design "D" collared coll assemblles wore sompleted. In both designs the Insulation applied to the cable was a 3 mil total bulld of polyimlde rilm obtalned pla splral wrapplng 1 mil materlat using a $2 / 3$ overlad. The labrlcation process starts by winding the upper inner cold ayer onto the andrel: It is inen rotated $80^{\circ}$ and the lower linner coll is wouna. The comoleted inner colls are flited with the inter-coll insulation and the assembly then clamped securely to the mandrel using thin polyester sands. These bands are :emporary and are removed later in the assemoly. The upper oucer cable is sollced to the Inner and wound over the inner coll/nter-soll insulation assemoly. The mandrel is apain rotated $180^{\circ}$ and the process repeated for the lower outer coll. Additional polyester flin Dands are used to elamp the entire assembly to the mandrel only at the ends, after which the bands around the lnner 2011 are cut and removed. Ground insulation is applited to the stralght section of the magnet only. Wth end Insulation deferred until later in the assemoly. The slanp collars are then applled to the stralght section of the assembly. The upper and lover collars are not prsssed home at this ilme, Instead they are engaged oniy with 1 ight clamping force surflctent to retaln the coll. The polyester bands on the ends are rewoved and end ground insulation Installed followed by assembly of the end collars. Clatiping force is applied to the collars in a preas designed for that purpose. The collars are not completely clamped at this time, oniy surflctent elamping corce is applied to assure ratial positioning of the colls via the stlll expanded aandrel and the collar. Once accomplished, the wandret is collasped and collar clanp force 1 nereased to completely close the collars. This assures proper radlal placewent of the colls withtn the collars. The claupling force is then released and the collars allowed to rebound. Ine mandral 19 then oxtracted and clanping force reapplied. The locking keys are then Installed into the collars completing the assembly.

\section{Fabrlcation Experlences}

Considerable dffrleultles that were encountored early on in the rabrleation of these angnets wor. almost ontirely aanifested in layer to layor coll shorts, priarily near the magnet ends. These shorts wern due to varlous sources which becane clearer as corrections were appl lod throughout the magnet serlea. Unllke vet wound colls wher the ables are bound to one another. the dry wound cables are tree to wove out of radial position. Through the stralght portion. this is hardly a problem. However, as one approaches the ends, stresses in the cable caused by bending result in the cable to radially push outward from the mandril. The result belng that the inner cable extrudes Into the space oceupled by the outer cable with a resultant interwearing of the Inner and outer coll layers. When the collars are applled and pressed to closure, the Incerveaved Inner and outer turns shear tinrough the Insulation system causing layer to layer (Inner to outer) shorts (F1g. 5). Th1s problew was remedied by replacing the 10 sil thickness polyinide Inter-layer insulation at the ands with a layar of 30 all inlek G10 (F18.6). The 610 is surflelently gilfe to prevent encroachment of the Inner windings into the outer windings.

Although this solution worked, It did not addreas the root causes of the proolero - namely bending the

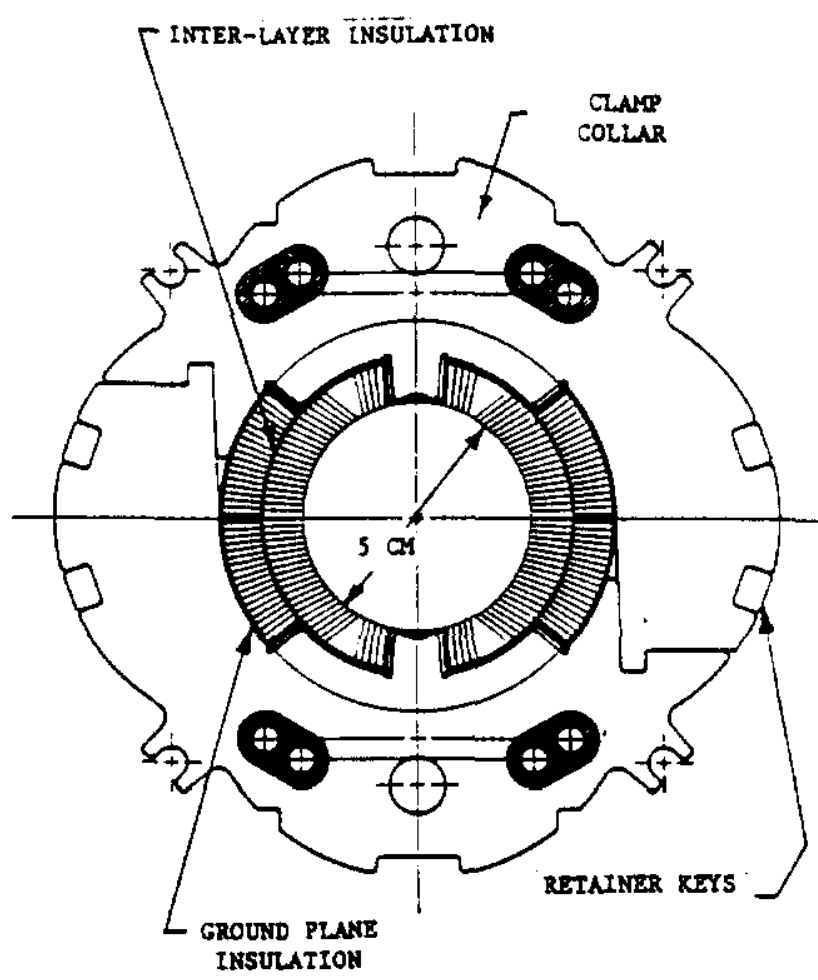

F18. 3. Ssc dealon "g" Collared coll cross Section

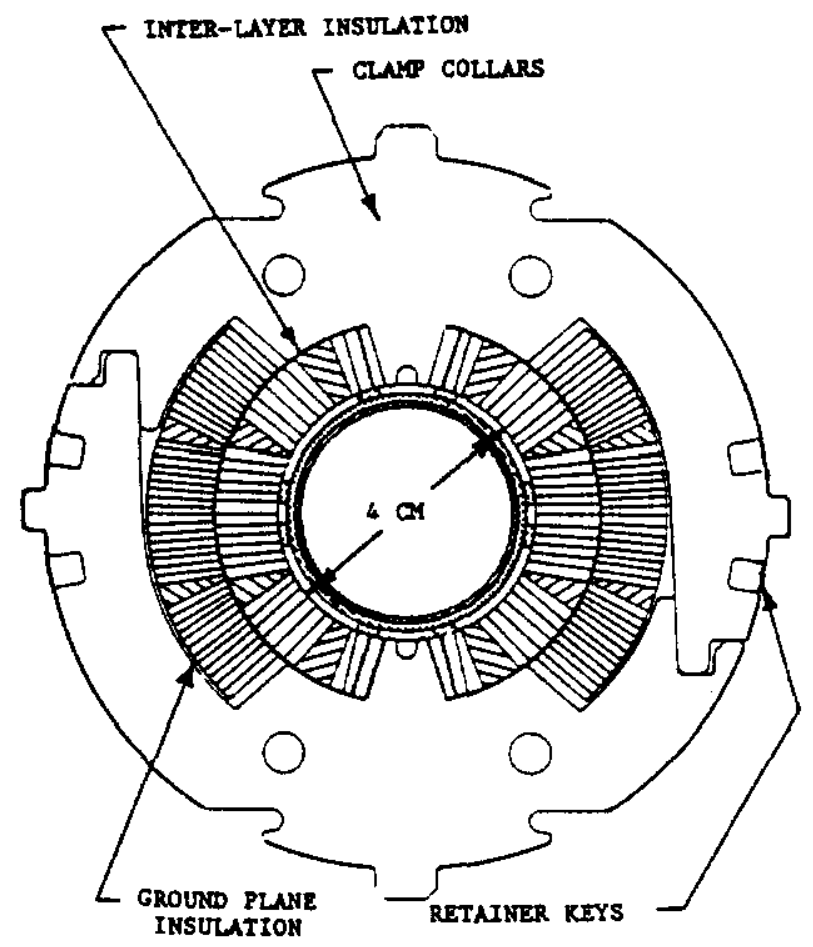

F18. *. SSC Dealgn "D" CS Cross Section 


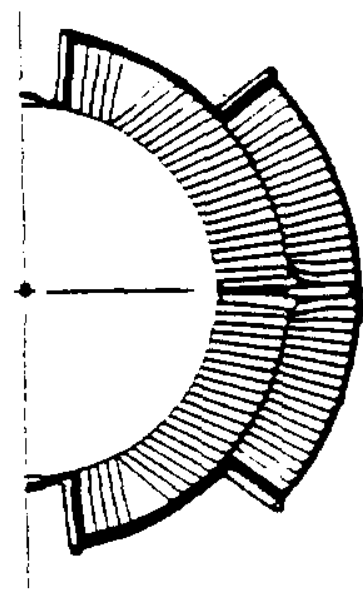

T1g. 5. Illustrating the encroactuent on inner cable windings into the outer winding.

caole at the ands without regard to the geometry required. To correct this condltion requires the use or a constant perimeter end geometrys allowing the cable windings to more slosely follow the cyllnorical for of the winding mandrel. Hand iltted end parts approximating constant perlateter ends were used with good results. Another contributor to layer-to-layer shorts ts the relative size and preload of the Inner and outer colt layer. Operationally, the Inner coil should de wore heavily preloaded than the outer coll. hovever, the dry ulnoling process would like the outer coll to have a higher preload thereby locklnc the outer cables together before the Inner coll loads can add to the encroachent problem. The solutions for controlling layer-tolayer shorts also help in laproving condictor placement (reduction in randoen harmonis arrors).

Turn-to-turn shorts were not a groble throughout the series. Shorts that did occur were in or near the ends and usually attributade to the same problens unleh caused byer-to-layer shorts.

Other problems were encountered at the angnet ends involving ground plane insulation. The Insulation inltialiy used was multi-layers of polylatce illa $(6 \times 5$ mil) elroumferenclally wrapped around the outer coll and clo end pll1ers. The

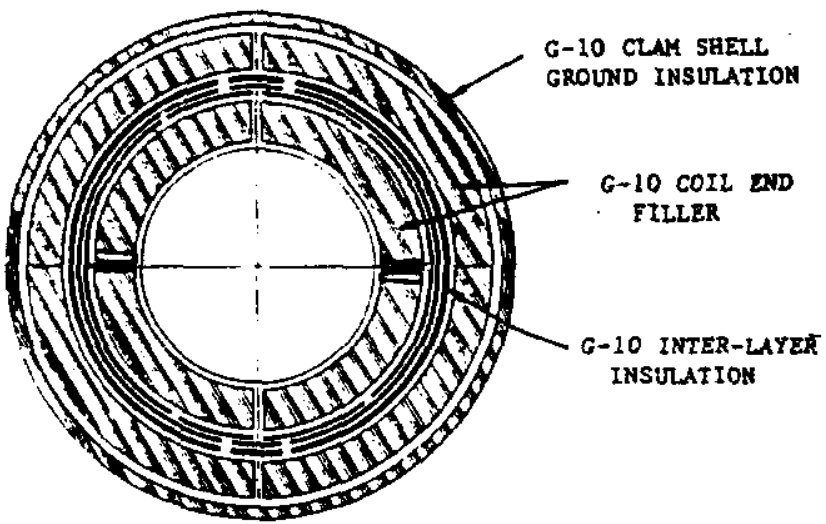

18. 6. Cross section through magnet end. looseness of the precollared package coupled with friction during the collaring operation cauad the insulation to wrinkle and woro tra 1 ts intended position oftan rabuiting in outer coil shorts to ground. Th1s was orercose by repleoint the polylselde 111. Wth a clan snoll Insulacor conalating or three laminated layers of 30 all $0-10$ (818. 6). The additional I nsulation thlokneds was accomodated oy undercuting the and collars.

\section{Roaults and Conclusion}

The angets produced in this serias perforned qu1te well conslderins the annet ends were not optinized eor asgnet performance. Peak fleld reduction was approxianted and proper compaction of the end winding was given 1fttle attention, iather the progras concentrated on the process and tooling for producling dry wound colls using tochniques applicabl to alas production. Magnet periorance is discussed in a companion paper ontitled "The 5 ca Aperture Dlpole Studiegn". The probleas encouncered are not indurwountable and have solutions but require additional ReD. Perfection or constant perluetor ends 1s of parawount importance. There are at last two benerits that oun be dertied eron the dry winding experlent. Coll tanuracturing iechnology in general can benef 1t eroe the use or the constant parleoter end and the beproved betnods or ceble nessuring in wet or dry wound agnets. The dry winding wethod of producling a collared coll ay also prove to to a rable, leas costly alternative to the traditional athod of aning a eagnet.

\section{Rererences}

1. C. Taylor, et al. "l Novel Epoxy-Free Conatruction Method ror Fabricating Dipole Magnets and Test Resulte", IEEE Transactlons on Nuclear seience, Vol. Hs-28, No, 3, 3283, June 1981.

2. J. A. Carson, at a., A Devioe for Preclsion Dimenstonal Menaurentent of Suparcondueting cable", Procendines to de published for ICFA, 1986.

3. Reference Dealgns study for U. S. Department of Energy, "Superconducting Supar Coil1der", May 8, 1984.

4. SSC Centrel Deatgn Group. "SSC Conceptual Deslgn Megnet Desi on Deta11a". Attachwent 8, March 1986.

5. H. I. Rosten, Rutharford Laboratory, "The Conatant Perinetor End". RL-73-096. Septenow 1973.

6. A. D. Malnture, et al, "The 5 at iparture Dipole Studiea", ASC 1986 (these proceedings). 